Supporting Information to

\title{
Nanochannel Templated Iridium Oxide Nanostructures for Wide-Range pH Sensing from Solutions to Human Skin Surface
}

\author{
Lin Zhou, ${ }^{+}$Chen Cheng, ${ }^{+}$Xinru Li, ${ }^{+}$Jialian Ding, ${ }^{+}$Qingjun $\mathrm{Liu}^{+}$and Bin $\mathrm{Su}^{+*}$ \\ + Department of Chemistry, Zhejiang University, Hangzhou 310058, China \\ $\neq$ Department of Biomedical Engineering, Zhejiang University, Hangzhou 310027, China
}

\section{Table of Contents}

S1. Literature Summary of $\mathrm{pH}$ Responses of $\mathrm{IrO}_{\mathbf{x}}$-Based Sensors

S2. Experiment Section

S3. Structure Characterization of SNM

S4. Structure Characterization of SNM/ITO, IOS/ITO and IOL/ITO

S5. Full XPS Spectra of IONW/ITO

S6. SWVs of IONW/ITO at Different Concentration of $\mathrm{NaCl}$ at $\mathrm{pH}=11.5$

S7. OCP-pH Responses of IONW/ITO in $\mathrm{NaNO}_{3}$ and $\mathrm{Na}_{2} \mathrm{SO}_{4}$ solutions

S8. SWVs of IONW@SNM/ITO at Different Concentrations of $\mathrm{NaCl}$

S9. Stability of IONW/ITO in Solutions

S10. OCP-pH Response of IONW/ITO in Base-to-Acid Direction

S11. OCP Responses to the Acidity of Organic Media

S12. Details on Flexible Epidermal pH Sensing

S13. Performance of pH Sensor under Different Bending States 


\section{S1. Literature Summary of pH Responses of IrO $_{x}$-Based Sensors}

Table S1 summarizes the preparation method, sample solution, sensitivity and response range of different types of $\mathrm{IrO}_{\mathrm{x}}-\mathrm{based}_{\mathrm{pH}} \mathrm{pensors}$. The IrO $\mathrm{x}^{-}$ based sensors were prepared by various methods, including heating, electrochemical oxidation, electrodeposition and chemical oxidation. The response of $\mathrm{IrO}_{\mathrm{x}}$-based sensors is sensitive to structure and composition of $\mathrm{IrO}_{\mathrm{x}}$, with a sensitivity varying from 49 to $80 \mathrm{mV} / \mathrm{pH}$ and a $\mathrm{pH}$ detection range from 1 to 13 .

Table S1 A Summary of different types of $\mathrm{IrO}_{\mathrm{x}}$-based sensors and sensitivities

\begin{tabular}{|c|c|c|c|c|}
\hline Sensor & Preparation Method & Sample Solution & Sensitivity (pH Range) & Reference \\
\hline $\mathrm{Pt} / \mathrm{IrO}_{\mathrm{x}}$ & Electrodeposition & $0.1 \mathrm{M} \mathrm{KCl}$ & $71.4 \mathrm{mV} / \mathrm{pH}(2-11)$ & 1 \\
\hline $\operatorname{Ir} / \mathrm{IrO}_{\mathrm{x}}$ microelectrode & Electrodeposition & $0.1 \mathrm{M} \mathrm{KCl}$ & $67.9 \mathrm{mV} / \mathrm{pH}(2-7.4)$ & 2 \\
\hline $\mathrm{TiO}_{2} / \mathrm{IrO}_{\mathrm{x}}$ & Pechini method & $0.1 \mathrm{M}$ Tris- $\mathrm{HCl}$ or Tris & $69.9 \mathrm{mV} / \mathrm{pH}(1-13)$ & 3 \\
\hline Ir microdisc electrode/IrO & Heating at $870^{\circ} \mathrm{C}$ & Saline & $57.5 \mathrm{mV} / \mathrm{pH}(1-10)$ & 4 \\
\hline $\mathrm{Pt} / \mathrm{IrO}_{\mathrm{x}}$ & Electrodeposition & $0.2 \mathrm{M}$ PBS & $74.0 \mathrm{mV} / \mathrm{pH}(3-11)$ & 5 \\
\hline $\mathrm{Pt} / \mathrm{IrO}_{\mathrm{x}}$ & Electrodeposition & $0.2 \mathrm{M}$ PBS & $77.5 \mathrm{mV} / \mathrm{pH}$ & 6 \\
\hline $\mathrm{IrO}_{x} / \mathrm{Au}$ microelectrode & Electrodeposition & $10 \mathrm{mM}$ PB & $75.6 \mathrm{mV} / \mathrm{pH}(4-10)$ & 7 \\
\hline $\mathrm{Pt} / \mathrm{IrO}_{\mathrm{x}}$ & Heating at $870{ }^{\circ} \mathrm{C}$ & $0.1 \mathrm{M} \mathrm{KCl}$ & $58.1 \mathrm{mV} / \mathrm{pH}(2-12)$ & 8 \\
\hline $\mathrm{Pt} / \mathrm{IrO}_{\mathrm{x}}$ & Electrodeposition & $1.0 \mathrm{M} \mathrm{KCl}$ & Not given & 9 \\
\hline $\mathrm{IrO}_{2} / \mathrm{Ag}$ & Heating & $0.1 \mathrm{M}$ Tris & $56.9 \mathrm{mV} / \mathrm{pH}(2-12.5)$ & 10 \\
\hline $\mathrm{IrO}_{2}$ nanofiber & Not given & $0.2 \mathrm{M}$ PBS & $62.32 \mathrm{mV} / \mathrm{pH}(3-12)$ & 11 \\
\hline Miniaturized $\mathrm{IrO}_{2}$ electrode & Heating & $0.1 \mathrm{M} \mathrm{KCl}$ & $49.7 \mathrm{mV} / \mathrm{pH}(1.5-12)$ & 12 \\
\hline $\mathrm{Ir} / \mathrm{IrO}$ & Heating at $870^{\circ} \mathrm{C}$ & Oilfield produced water & $58.9 \mathrm{mV} / \mathrm{pH}(2-12)$ & 13 \\
\hline $\mathrm{IrO}_{\mathrm{x}} / \mathrm{ITO}$ & Electrodeposition & $1.0 \mathrm{M} \mathrm{PB}$ & $60 \mathrm{mV} / \mathrm{pH}(2-6)$ & 14 \\
\hline $\mathrm{Ir} / \mathrm{IrO}_{\mathrm{x}}$ microelectrode & Electrochemical oxidation & Commercial standard pH buffer solutions & $73.61 \mathrm{mV} / \mathrm{pH}(2-12)$ & 15 \\
\hline PDDA-IrO $/$ /ITO/PET & Print & Commercial standard pH buffer solutions & $58.57 \mathrm{mV} / \mathrm{pH}(2.91-10.3)$ & 16 \\
\hline $\mathrm{IrO}_{2}-\mathrm{RuO}_{2}-\mathrm{TiO}_{2}$ film & Heating & $0.1 \mathrm{M}$ Tris & $59.16 \mathrm{mV} / \mathrm{pH}(1.6-10.6)$ & 17 \\
\hline $\mathrm{Ir} / \mathrm{IrO}_{\mathrm{x}}$ & Heating & Not given & $59 \mathrm{mV} / \mathrm{pH}(2-13)$ & 18 \\
\hline
\end{tabular}




\begin{tabular}{|c|c|c|c|c|}
\hline $\mathrm{Ir} / \mathrm{IrO}_{\mathrm{x}}$ & Electrochemical oxidation & $1.0 \mathrm{M} \mathrm{PB}$ & $78 \mathrm{mV} / \mathrm{pH}(2-13)$ & 19 \\
\hline $\mathrm{Ir} / \mathrm{IrO}_{\mathrm{x}}$ & Chemical oxidation & Commercial standard pH buffer solutions & $60 \mathrm{mV} / \mathrm{pH}(6-10)$ & 20 \\
\hline $\mathrm{Ir} / \mathrm{IrO}$ & Chemical oxidation & $0.5 \mathrm{M} \mathrm{NaCl}$ & $\begin{array}{c}74 \mathrm{mV} / \mathrm{pH}(4.6-10) \\
\left(100{ }^{\circ} \mathrm{C}, 25 \mathrm{Mpa}\right)\end{array}$ & 21 \\
\hline $\mathrm{Au} / \mathrm{IrO}_{\mathrm{x}}$ & Electrochemical oxidation & $0.1 \mathrm{M} \mathrm{NaCl}$ & $70.1 \mathrm{mV} / \mathrm{pH}(2-12)$ & 22 \\
\hline $\mathrm{Ir} / \mathrm{IrO}_{\mathrm{x}}$ & Electrochemical oxidation & Not given & $73.6 \mathrm{mV} / \mathrm{pH}(2.5-10.5)$ & 23 \\
\hline $\mathrm{Ir} / \mathrm{IrO} \mathrm{x}_{\mathrm{x}}$ & Heating at $870^{\circ} \mathrm{C}$ & $0.1 \mathrm{M} \mathrm{KCl}$ & $58.4 \mathrm{mV} / \mathrm{pH}(2-12)$ & 24 \\
\hline $\mathrm{Pt} / \mathrm{IrO}_{\mathrm{x}}$ & Electrodeposition & Commercial standard pH buffer solutions & $61.7 \mathrm{mV} / \mathrm{pH}(1.2-12.5)$ & 25 \\
\hline $\mathrm{Pt} / \mathrm{IrO}_{\mathrm{x}}$ & $\begin{array}{c}\text { Anodic electrochemical } \\
\text { process }\end{array}$ & $\mathrm{pH}$ buffer solutions & $75.5 \mathrm{mV} / \mathrm{pH}(1-13)$ & 26 \\
\hline $\mathrm{GC} / \mathrm{IrO}_{\mathrm{x}}$ & Electrodeposition & PB & $\begin{array}{c}64.1 \mathrm{mV} / \mathrm{pH}(2-6) \text { and } 72 \\
\mathrm{mV} / \mathrm{pH}(6-12)\end{array}$ & 27 \\
\hline $\mathrm{Pt} / \mathrm{IrO}_{\mathrm{x}}$ & Electrodeposition & Commercial standard pH buffer solutions & $77.6 \mathrm{mV} / \mathrm{pH}(4-10)$ & 28 \\
\hline $\mathrm{Au} / \mathrm{IrO}_{\mathrm{x}}$ & Sol-gel process & $\mathrm{KCl}$ solution & $59 \mathrm{mV} / \mathrm{pH}$ & 29 \\
\hline
\end{tabular}




\section{S2. Experiment Section}

\section{Chemicals and Materials}

All chemicals and reagents were analytical grade or higher, and used as received without further purification. Cetyltrimethylammonium bromide (CTAB, 98\%), tetraethoxysilane (TEOS, 99.0\%), and

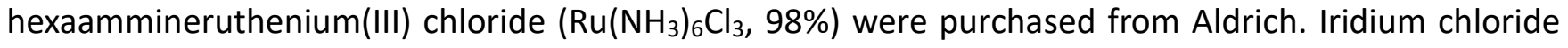
hydrate $\left(\mathrm{IrCl}_{3} \cdot \mathrm{H}_{2} \mathrm{O}, \mathrm{Ir}>63.9 \%\right)$, hydrogen peroxide $\left(\mathrm{H}_{2} \mathrm{O}_{2}, 30\right.$ wt.\%), oxalic acid hydrate $\left((\mathrm{COOH})_{2} \cdot \mathrm{H}_{2} \mathrm{O}\right.$, $98 \%)$, potassium carbonate $\left(\mathrm{K}_{2} \mathrm{CO}_{3}, 99.5 \%\right)$, potassium ferricyanide $\left(\mathrm{K}_{3} \mathrm{Fe}(\mathrm{CN})_{6}, \geq 99.0 \%\right)$, hydroxymethylferrocene $(\mathrm{FcMeOH},>95 \%)$, sodium chloride $(\mathrm{NaCl}, 99.5 \%)$, sodium nitrate $\left(\mathrm{NaNO}_{3}\right.$, 99.0\%), sodium sulfate $\left(\mathrm{Na}_{2} \mathrm{SO}_{4}, 99.0 \%\right)$, Trifluoroacetic acid $\left(\mathrm{CF}_{3} \mathrm{COOH}, 99.0 \%\right)$, acetonitrile $\left(\mathrm{CH}_{3} \mathrm{CN},>\right.$

99.0\%) and 1,2-dichloroethane (DCE, > 99.0\%) were bought from Aladdin. Bis(triphenylphosphoranylidene)ammonium chloride (BACl, 97.0\%) and potassium tatrakis(4chlorophenyl)borate (KTPBCl, > 98.0\%) were bought from Alfa Aesar. BATPBCl was synthesized by metathesis of $1: 1$ mixture of $\mathrm{BACl}$ and $\mathrm{KTPBCl}$ in the mixture of methanol and water $(\mathrm{v} / \mathrm{v}=2 / 1)$, followed by filtratration and drying at $60{ }^{\circ} \mathrm{C}$. Indium tin oxide (ITO) coated glass electrode ( $<15 \Omega /$ square, $100 \pm$ $20 \mathrm{~nm}$ ) was purchased from Zhuhai Kaivo. All aqueous solutions were prepared with ultrapure water (18.2 M $\Omega \mathrm{cm}$, Milli-Q, Millipore). Artificial cerebrospinal fluid (aCSF) was prepared by adding $\mathrm{NaCl}$ (126 mmol), $\mathrm{KCl}(2.4 \mathrm{mmol}), \mathrm{KH}_{2} \mathrm{PO}_{4}(0.5 \mathrm{mmol}), \mathrm{NaHCO}_{3}(27.5 \mathrm{mmol}), \mathrm{Na}_{2} \mathrm{SO}_{4}(0.5 \mathrm{mmol}), \mathrm{MgCl}_{2}$ (0.85 mmol) and $\mathrm{CaCl}_{2}(1.1 \mathrm{mmol})$ into $1.0 \mathrm{~L}$ of ultrapure water. The $\mathrm{pH}$ of aCSF was adjusted to $7.2-7.4$ with concentrated $\mathrm{HCl}$ and $\mathrm{NaOH}$. The aCSF was stored at $4{ }^{\circ} \mathrm{C}$ for use.

\section{Preparation of SNM/ITO}

The SNM/ITO electrode was prepared by the Stöber-solution growth approach as previously reported. ${ }^{30}$ Firstly, the precursor solution was prepared by mixing $160 \mathrm{mg}$ of CTAB, $30 \mathrm{~mL}$ of ethanol, $70 \mathrm{~mL}$ of water, $10 \mu \mathrm{L}$ of ammonia aqueous solution and $80 \mu \mathrm{L}$ of TEOS. Subsequently, the ITO electrode was immersed in the precursor solution and the SNM was grown on the surface under quiescent condition at $60{ }^{\circ} \mathrm{C}$ for $24 \mathrm{~h}$. The prepared SNM/ITO electrode was then rinsed with water and aged at $100{ }^{\circ} \mathrm{C}$ for $12 \mathrm{~h}$. CTAB micelles in silica nanochannels were removed by immersing the SNM/ITO electrode in $0.1 \mathrm{M} \mathrm{HCl}$ ethanol solution under mild stirring for $20 \mathrm{~min}$.

\section{Preparation of Electrodeposition Solution}

The electrodeposition solution was prepared as previously reported by Yamanaka et al. ${ }^{14}$ Typically, 82.65 $\mathrm{mg}$ of $\mathrm{IrCl}_{3} \cdot \mathrm{H}_{2} \mathrm{O}$ was dissolved in $50 \mathrm{~mL}$ of water under magnetic stirring for $30 \mathrm{~min}$, to which $0.5 \mathrm{~mL}$ of $\mathrm{H}_{2} \mathrm{O}_{2}(30 \mathrm{wt} . \%)$ and $0.25 \mathrm{~g}$ of $(\mathrm{COOH})_{2} \cdot 2 \mathrm{H}_{2} \mathrm{O}$ were subsequently added under mild stirring. Then, the $\mathrm{pH}$ 
of resulting mixture was adjusted to 10.5 using $\mathrm{K}_{2} \mathrm{CO}_{3}$. Finally, the electrodeposition solution was heated at $50{ }^{\circ} \mathrm{C}$ for $5 \mathrm{~h}$ until the color changed to dark blue. The electrodeposition solution was stored at $4{ }^{\circ} \mathrm{C}$ under dark for use.

\section{Preparation of IONW/ITO electrode - Electrodeposition}

The electrodeposition of IONWs within nanochannels of SNM/ITO electrode was performed using chronopotentiometry in a three-electrode configuration. As illustrated in Scheme 1, the SNM/ITO electrode with a surface area of $2.5 \mathrm{~cm}^{2}$ functioned as the working electrode, a platinum wire and a silver/silver chloride (saturated by $\mathrm{KCl}$ ) as the counter and reference electrodes, respectively. A constant current density of $0.08 \mathrm{~mA} / \mathrm{cm}^{2}$ was applied. The obtained IONW@SNM/ITO electrode was immersed in 1.0 $\mathrm{M} \mathrm{NaOH}$ aqueous solution at room temperature to etch SNM, eventually producing the IONW/ITO electrode. The $\mathrm{IrO}_{x}$ modified ITO electrode $(\mathrm{IO} / \mathrm{ITO})$ was prepared by electrodepositing $\mathrm{IrO}_{\mathrm{x}}$ with a constant current density of $0.08 \mathrm{~mA} / \mathrm{cm}^{2}$ for $40 \mathrm{~s}$.

\section{Characterization of SNM and IONWs}

Scanning electron microscopic (SEM), transmission electron microscopic (TEM) and high-resolution TEM measurements were conducted on a field emission scanning electron microscope (SU-8020, Hitachi, Japan), a HT7700 transmission electron microscope (Hitachi, Japan) and a JEM-2100F transmission electron microscope (JEOL, Japan), respectively. The TEM specimens were prepared by mechanically peeling of SNM and IONWs grown on the ITO electrode, dispersing in water and ethanol mixture solution in a volume ratio of $1 / 1(\mathrm{v} / \mathrm{v})$, and dropping onto the copper grid or ultrathin pure carbon film, respectively.

X-Ray photoelectron spectroscopy (XPS) spectra were recorded on a VG ESCALAB MARK II system (VG, UK). X-Ray diffraction patterns recorded on a DX-2700 spectrometer (Aolong, China). The XRD specimen was prepared by mechanically peeling of SNM and IONWs grown on the ITO electrode, dispersing in water and ethanol mixture solution in a volume ratio of $1 / 1(\mathrm{v} / \mathrm{v})$, and dropping onto the clean glass slide.

\section{Electrochemistry Measurements}

Electrodeposition and all other electrochemistry experiments were performed on an Autolab electrochemical workstation (PGSTAT302N, Metrohm). The open circuit potential (OCP) measurement was performed in a two-electrode configuration. In aqueous solutions, a $\mathrm{Ag} / \mathrm{AgCl}$ (saturated $\mathrm{KCl}$ solution) was used as the reference electrode. $1.0 \mathrm{M} \mathrm{NaCl}$ was added as the supporting electrode to maintain the ionic strength. $\mathrm{HCl}$ and $\mathrm{NaOH}$ were used for adjusting solution $\mathrm{pH}$. In organic solutions, BATPBCl was used as the supporting electrolyte and a AgTPBCl/Ag electrode as the reference electrode. The acidicity 
of organic solution was varied by the addition of $\mathrm{CF}_{3} \mathrm{COOH}$.

The voltammetric measurements were also performed in a three-electrode configuration, the same with electrodeposition experiment. The parameters for square wave voltammetry were as follows: the Incr E was $0.005 \mathrm{~V}$, Amplitude was $0.05 \mathrm{~V}$ and Frequency was $5 \mathrm{~Hz}$. 


\section{S3. Structure Characterization of SNM}

Figure S1 shows the top-view and cross-section TEM images of SNM. Apparently, the SNM consists of highly ordered and closely packed nanopores, with a diameter of ca. $2.3 \mathrm{~nm}$. The porosity is roughly $17 \%$ (see Figure S1a). The SNM consisted of parallel nanochannels with a thickness of roughly $101.9 \mathrm{~nm}$ (see Figure S1b).
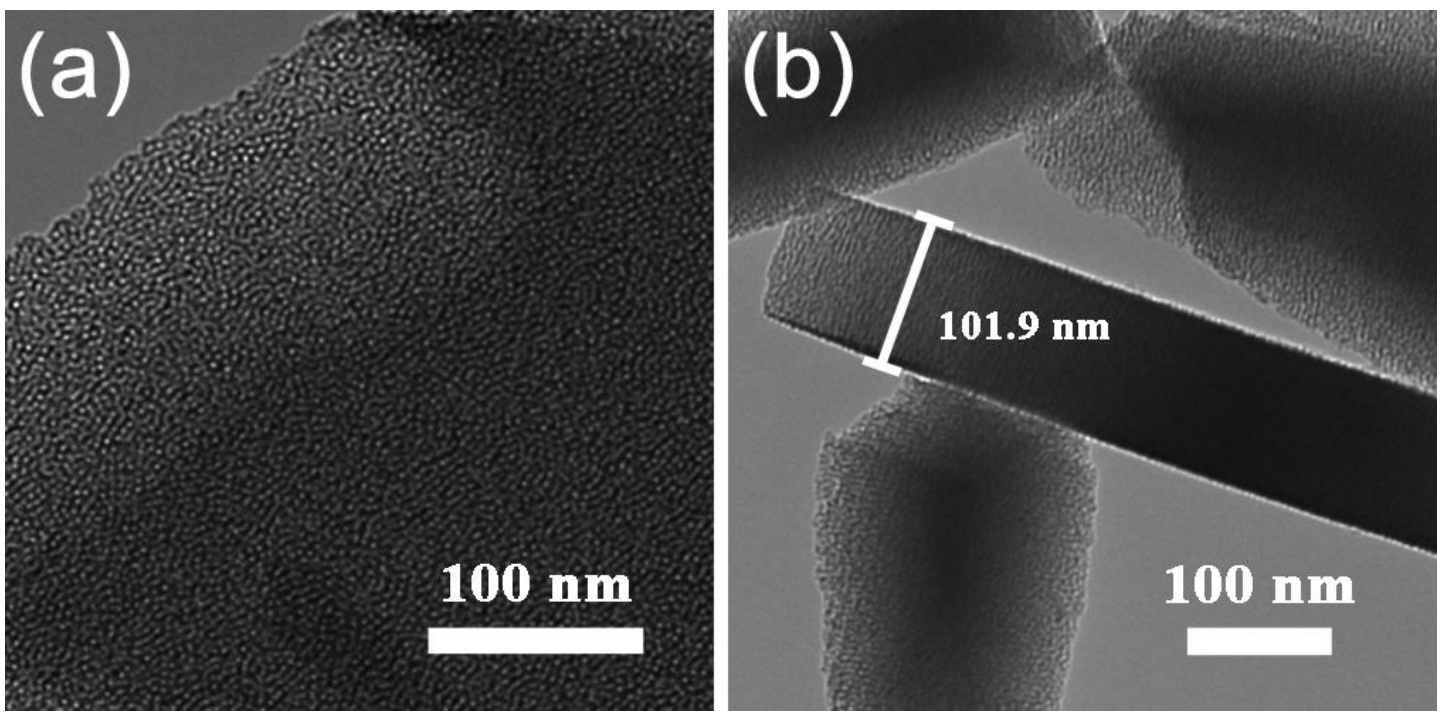

Figure S1. Transmission electron microscopy (TEM) images showing the top-view (a) and cross-section view (b) of SNM with scale bars annotated in images. 


\section{S4. Structure Characterization of SNM/ITO, IOS/ITO and IOL/ITO}

Figure S2 shows the cross-section SEM images of SNM/ITO (after chemical etching), IOS/ITO and IOL/ITO electrodes, respectively.

As displayed in Figure S2a, no SNM was observed on the ITO electrode surface, indicating the chemical etching of SNM in $1.0 \mathrm{M} \mathrm{NaOH}$ solution was effective.

As shown in Figure $\mathbf{S 2} \mathbf{b}$, if the electrodeposition was ceased at $9 \mathrm{~s}$ (blue period in Figure 1a), IONWs were barely observed on the ITO electrode surface, indicating only $\mathrm{IrO}_{x}$ seeds were possibly formed (the obtained electrode was designated as IOS/ITO electrode).

As shown in Figure S2c, when the electrodeposition time was extended up to $80 \mathrm{~s}$ (green period in Figure 1a), the electrodeposition of $\mathrm{IrO}_{\mathrm{x}}$ exceeded channels of SNM to from a cover layer on the top (the obtained electrode was named as IOL/ITO electrode). $\mathrm{IrO}_{x}$ particles were also observed, and the overall thickness of IOL was larger than that of SNM.
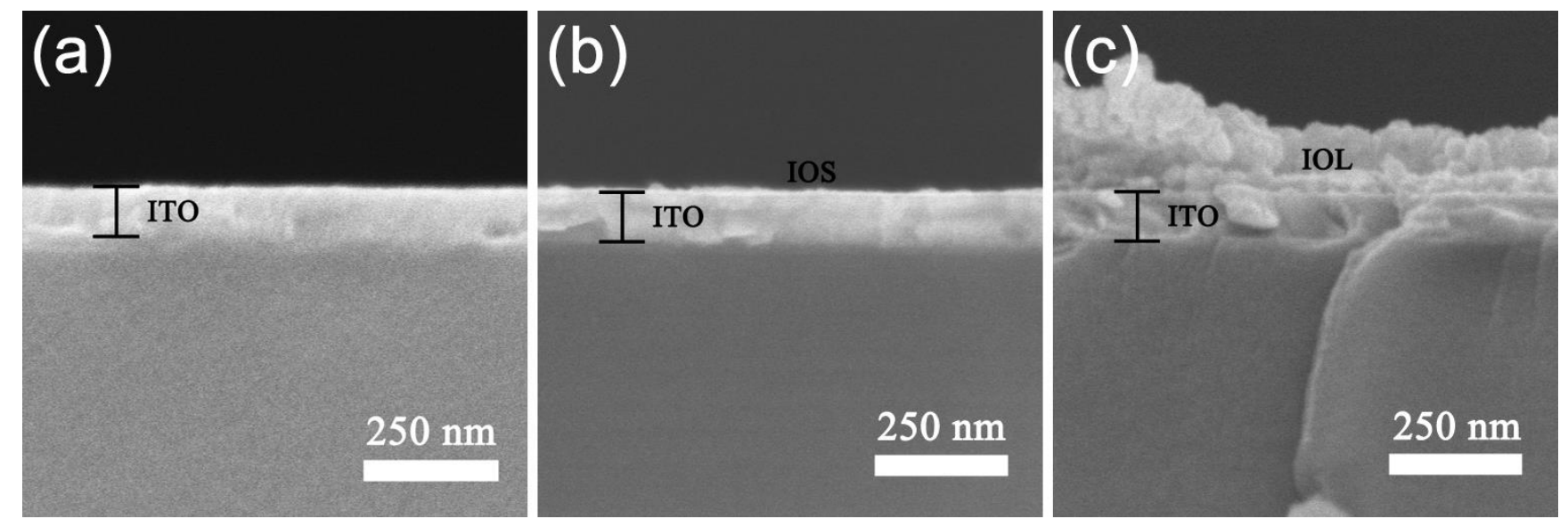

Figure S2. Cross-section SEM images of SNM/ITO (after chemical etching) (a), IOS/ITO (b) and IOL/ITO (c) electrodes with scale bars annotated in images. 


\section{S5. Full XPS Spectra of IONW/ITO}

Figure S3 dispalys the full XPS spectra of freshly prepared IONW/ITO, and that after acidic treatment and basic treatment, showing IONWs are mainly composed of iridium and oxygen. Moreover, as shown in Figure S3c, a remarkable peak of $\mathrm{Cl} 2 \mathrm{p}$ is displayed after acidic treatment of IONW/ITO at pH $=2.1$. The Ir $4 \mathrm{f}$ line of the IONW/ITO was $62.4 \mathrm{eV}$ of $\operatorname{Ir} 4 f_{7 / 2}$ and $65.4 \mathrm{eV}$ of $\operatorname{Ir} 4 f_{5 / 2}$. The Ir $4 \mathrm{f}$ line of IONW/ITO shifted away from the position of the rutile $\mathrm{IrO}_{2}$, which indicated that the electrodeposited IONWs was amophous $\mathrm{IrO}_{x} \cdot{ }^{31-34}$ The result was well matched with the XRD pattern of IONWs (see Figure 1f).
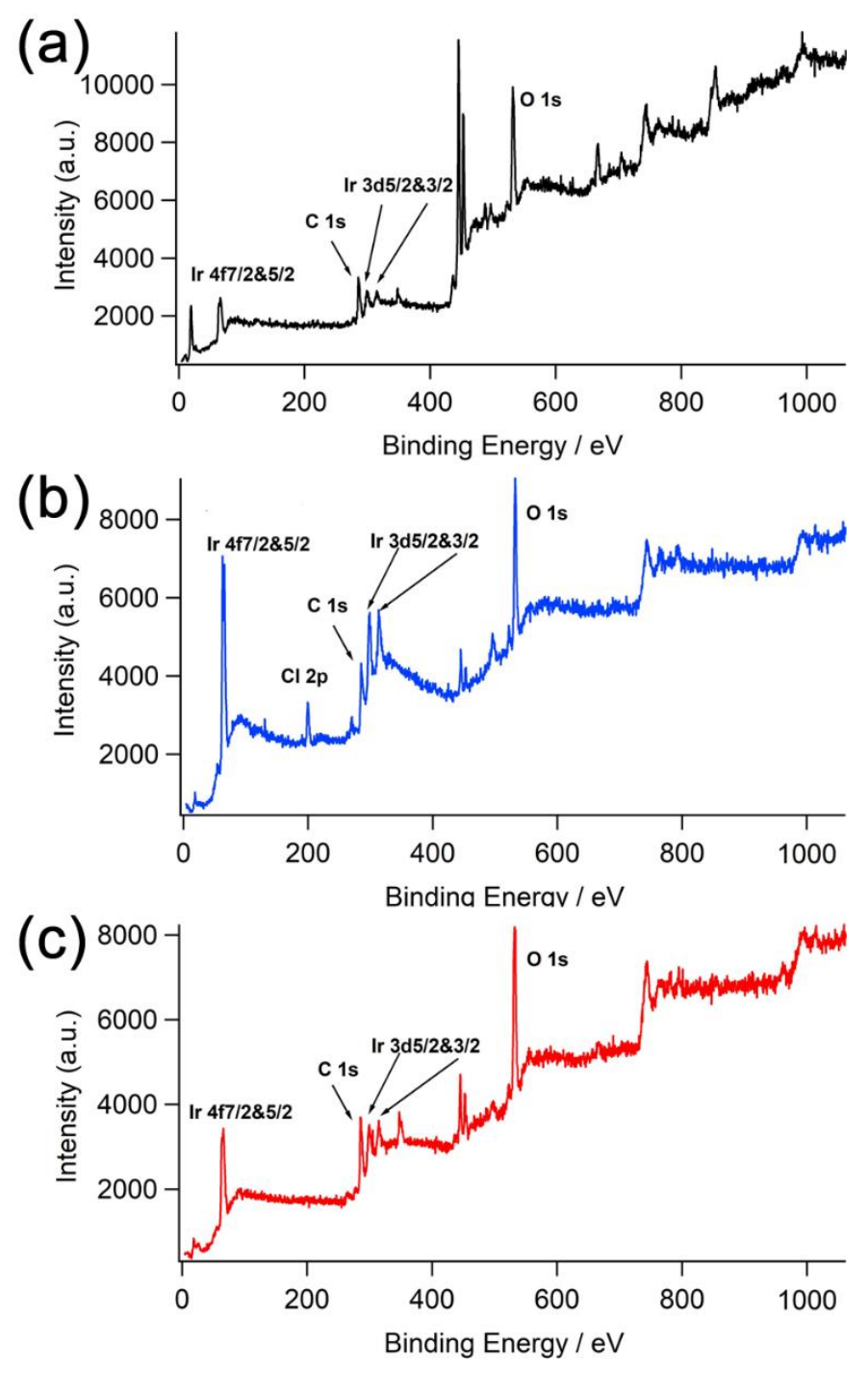

Figure S3. Full XPS spectra of freshly prepared IONW/ITO electrode (a), and that after acidic treatment (b) and basic treatment (c). 


\section{S6. SWVs of IONW/ITO at Different Concentrations of $\mathrm{NaCl}$ at $\mathrm{pH}=11.5$}

Figure S4a displays CV of an IONW/ITO electrode in $1.0 \mathrm{M} \mathrm{NaCl}$ at $\mathrm{pH}=11.5$, in which a pair of redox peak was observed at ca. $-0.31 \mathrm{~V}$.

Figure S4b shown SWVs of an IONW/ITO electrode in solutions containing different concentrations of $\mathrm{NaCl}$ at $\mathrm{pH}=11.5$. No potential shift was found by changing the concentraion of $\mathrm{NaCl}$ (as displayed in Figure S4c), indicating that $\mathrm{Cl}^{-}$did not participate the redox reaction of iridium oxyhydroxides in very basic solutions.
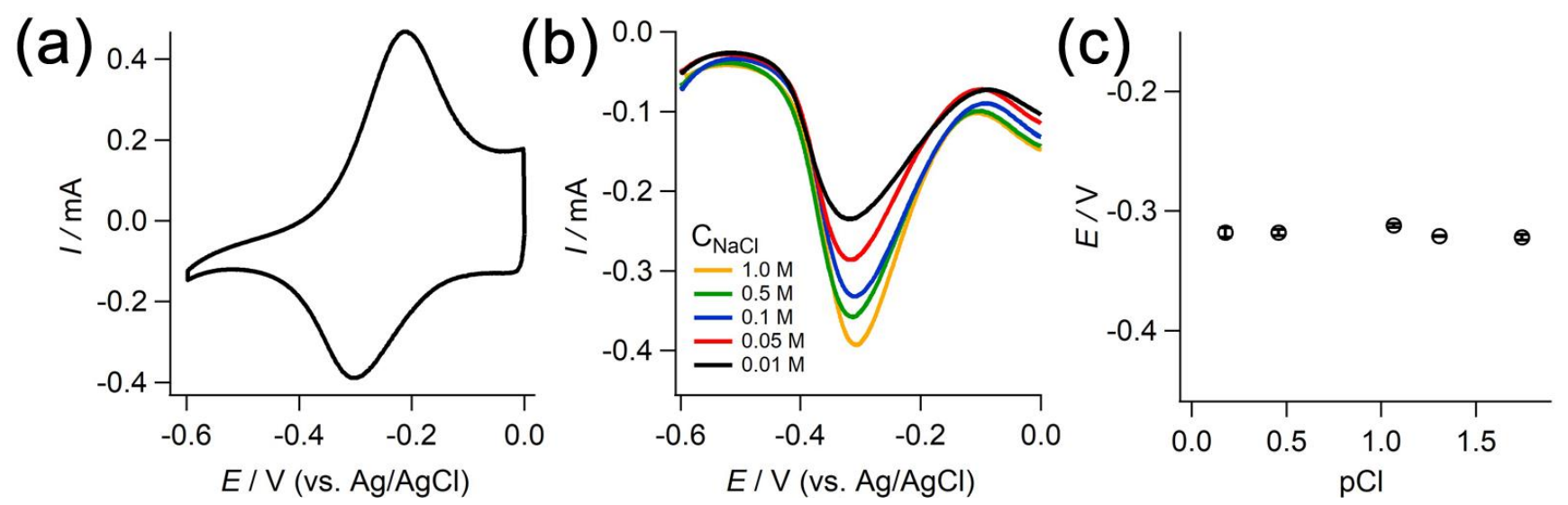

Figure S4. (a) $\mathrm{CV}$ of an IONW/ITO electrode in $1.0 \mathrm{M} \mathrm{NaCl}$ solutions at $\mathrm{pH}=11.5$. The scan rate was $100 \mathrm{mV} / \mathrm{s}$. (b) SWVs of an IONW/ITO electrode in solutions containing different concentrations of $\mathrm{NaCl}$ at $\mathrm{pH}=11.5$. (c) The dependence of SWV peak potentials shown in (b) on $\mathrm{pCl}$. 


\section{S7. OCP-pH Responses of IONW/ITO in $\mathrm{NaNO}_{3}$ and $\mathrm{Na}_{2} \mathrm{SO}_{4}$ Solutions}

Figure S5 displays the OCP-pH response of an IONW/ITO electrode in $1.0 \mathrm{M} \mathrm{NaNO}_{3}$ and $\mathrm{Na}_{2} \mathrm{SO}_{4}$ solutions. The high sensitivity in the very acidic range was not found in these two solutions. Instead, only one linear range with sensitivities of around $-90 \mathrm{mV} / \mathrm{pH}$ were achieved. The results further suggested that the ultra-high sensitivity in very acidic solutions $(\mathrm{pH}<2.5)$ was induced by participation of $\mathrm{Cl}^{-}$in the redox reaction.

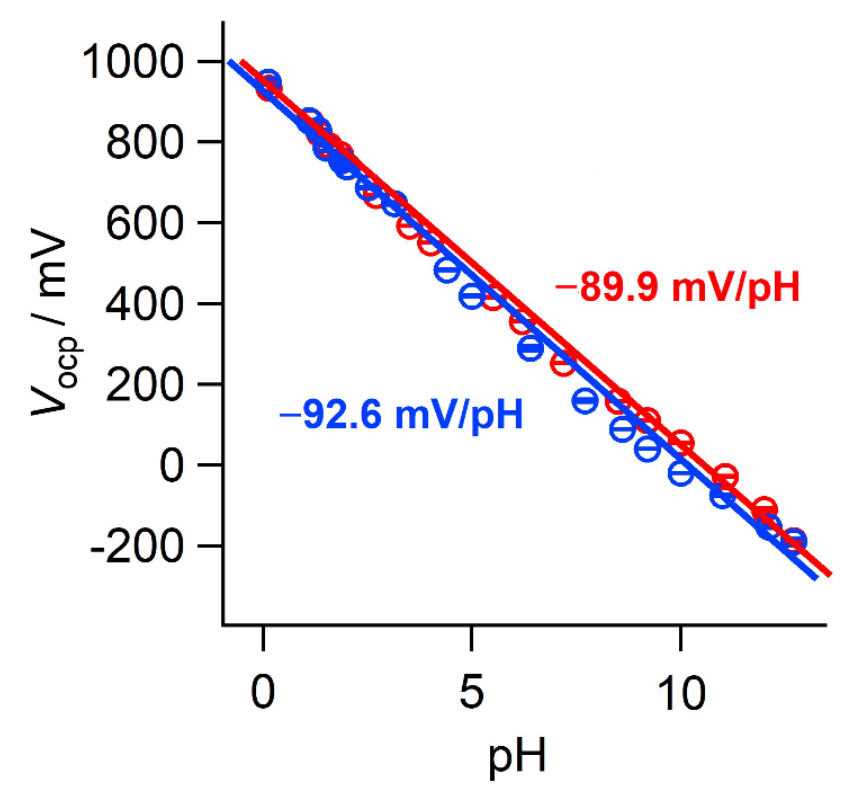

Figure S5. OCP-pH responses of an IONW/ITO electrode in $1.0 \mathrm{M} \mathrm{NaNO}_{3}$ (red line) and $\mathrm{Na}_{2} \mathrm{SO}_{4}$ (blue line) solutions. 


\section{S8. SWVs of IONW@SNM/ITO at Different Concentrations of $\mathrm{NaCl}$}

Figure S6a and c displays SWVs of an IONW@SNM/ITO electrode in solutions containing different concentrations of $\mathrm{NaCl}$ at $\mathrm{pH}=2.1$ and 11.5. The peak current was smaller than an IONW/ITO electrode, indicating that only terminal head faces were exposed to the solution. The reduction peak potential of IONW@SNM/ITO did not shift with increasing the concentration of $\mathrm{Cl}^{-}$in both acidic and basic conditions (see Figure S6b and d), suggesting that $\mathrm{Cl}^{-}$was not involved in the redox reaction.
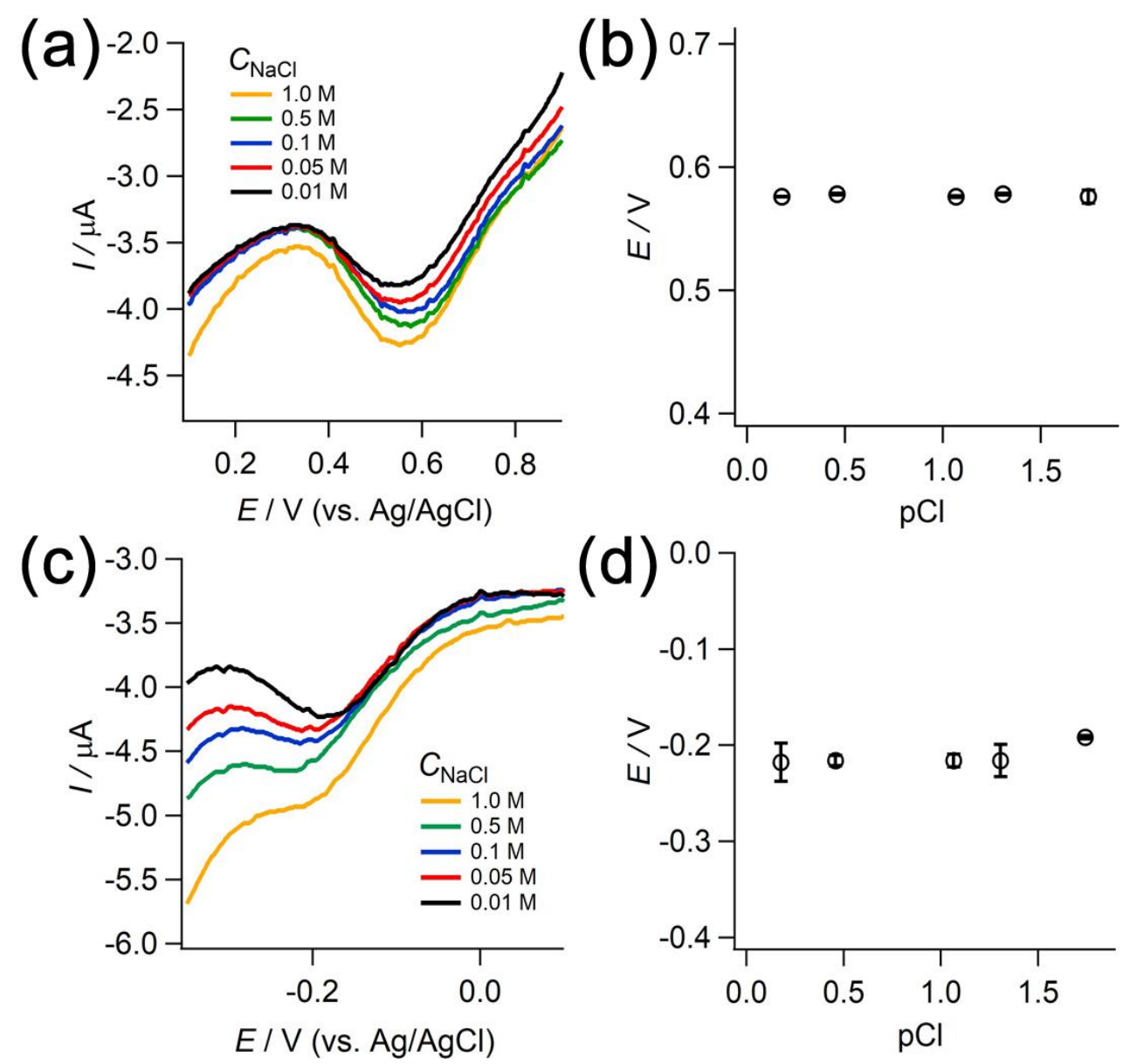

Figure S6. (a, c) SWVs of an IONW@SNM/ITO electrode in solutions containing different concentrations of $\mathrm{NaCl}$ at $\mathrm{pH}$ $=2.1$ (a) and 11.5 (c). (b, d) The dependence of SWV peak potentials shown in (b, d) on pCl. 


\section{S9. Stability of IONW/ITO in Solutions}

The stability of IONW/ITO in acidic and basic solutions were investigated by treating directly the IONW/ITO in solutions at $\mathrm{pH}=2.1$ and 11.5 for $2 \mathrm{~h}$, and the $\mathrm{CV}$ curves before and after immersing were recorded. As shown in Figure S7, the CV curves obtained after $2 \mathrm{~h}$ of immersion were well matched with that before immersion. No variation of peak position and peak current were observed. The results suggested the high stability of IONW/ITO under continuous immersing in acidic and basic conditions.
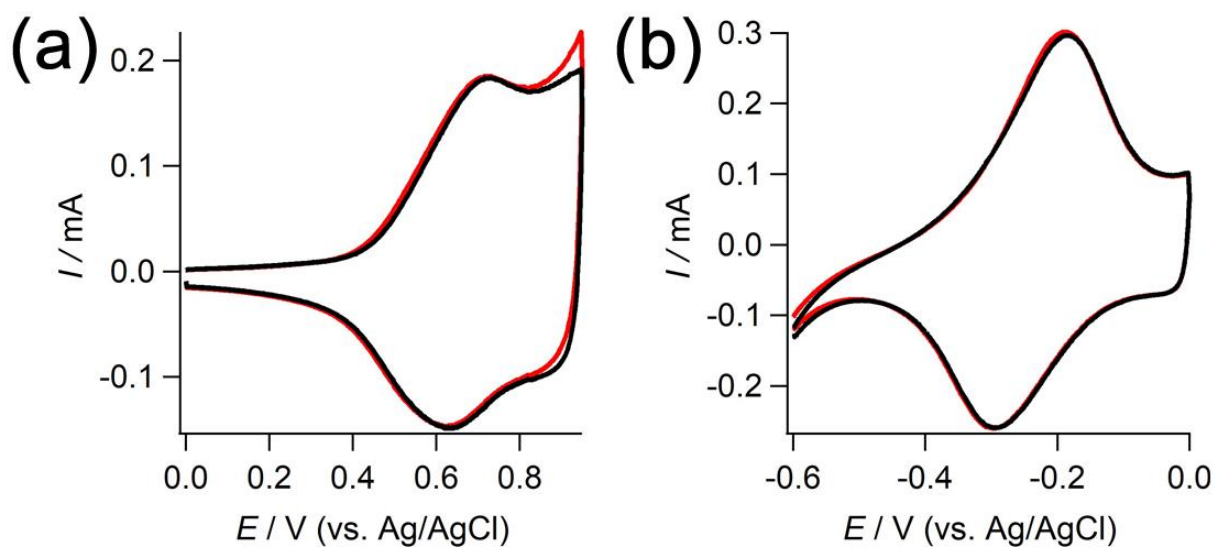

Figure S7. CVs of an IONW/ITO electrode before (red curves) and after (black curves) being immersed in solutions at $\mathrm{pH}=2.1(\mathrm{a})$ and $11.5(\mathrm{~b})$ for $2 \mathrm{~h}$. 


\section{S10. OCP-pH Response of IONW/ITO in Base-to-Acid Direction}

Figure S8 displays the OCP-pH response of IONW/ITO in the base to acid direction. Two linear ranges with a slope of $-89.9 \mathrm{mV} / \mathrm{pH}$ and $-232.2 \mathrm{mV} / \mathrm{pH}$ were observed. The sensitivities were well matched with that obtained in the acid-to-base direction (see Figure $\mathbf{2 b}$ ). It confirmed the good reversibility of the IONW/ITO electrode.

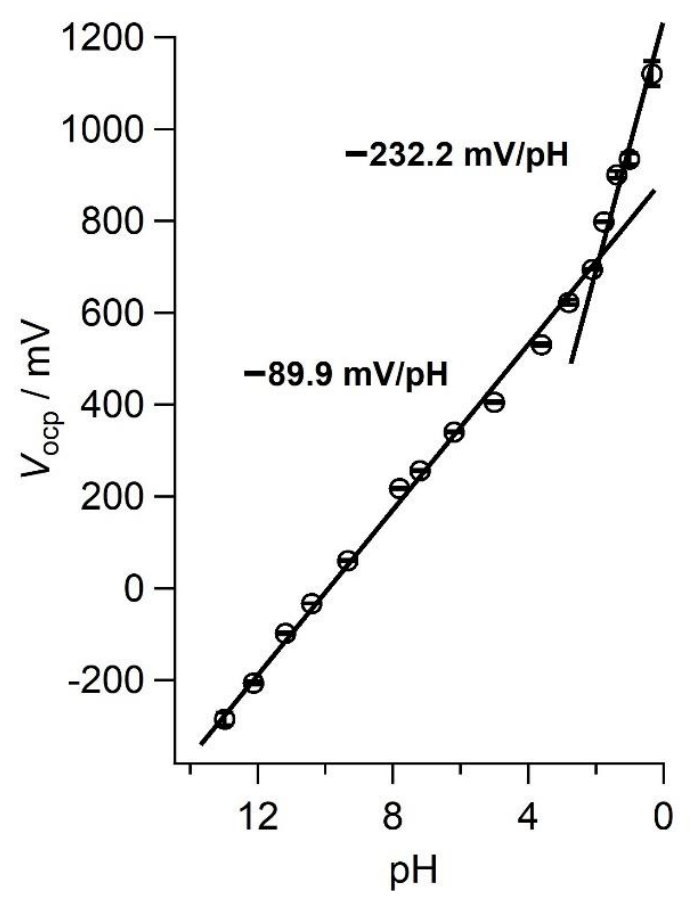

Fig. S8. OCP-pH response of the IONW/ITO in base-to-acid direction. 


\section{S11. OCP Responses to the Acidity of Organic Media}

The IONW/ITO also exhibited the potential for acidity responses in organic media. The OCP-acidity responses in both polar and low polar organic solvents were investigated. Figure S9a displays the OCP$C_{\text {TFA }}$ responses in concentration range of 0 to $5 \mathrm{mM}$. The OCP shifts to positive potentials with increasing the concentration of trifluoroacetic acid (TFA), the $\Delta V_{\text {OCP }}$ showing a linear dependence on $\operatorname{In} C_{\text {TFA }}$ by 23.4 $\mathrm{mV} / \mathrm{InC}_{\mathrm{TFA}}$ and $21.4 \mathrm{mV} / \mathrm{InC}_{\mathrm{TFA}}$ in acetonitrile and dichloroethane (see Figure S9b). Acetonitrile and dichloroethane contain a certain amount of water. Thus, we presumed that the redox reaction involving drated oxyhydroxides still could take place in that orgainc mediae. The redox reaction can be assumed to take place as follows,

$$
2\left[\mathrm{IrO}_{2}(\mathrm{OH})_{2}\right]_{(\mathrm{s})}^{2-}+3 \mathrm{H}_{(o)}^{+}+2 \mathrm{e}^{-}=\left[\mathrm{Ir}_{2} \mathrm{O}_{3}(\mathrm{OH})_{3}\right]_{(\mathrm{s})}^{3-}+2 \mathrm{H}_{2} \mathrm{O}_{(o)}
$$

with the Nernst equation expressed as,

$$
E=E_{\mathrm{a}}^{\ominus}+\frac{R T}{2 F} \ln \left(a_{\mathrm{H}^{+}}\right)^{3}=E_{\mathrm{a}}^{\ominus}+\frac{3 R T}{2 F} \ln \sqrt{K_{\mathrm{a}} C_{\text {TFA }}}=E_{\mathrm{a}}^{\ominus}+\frac{3 R T}{4 F} \ln K_{a}+\frac{3 R T}{4 F} \ln C_{\text {TFA }}
$$

where $E_{\mathrm{a}}^{*}$ is the standard potential, $K_{a}$ is the dissociation constant and $a_{\mathrm{H}^{+}}$the proton activity. $R, T$ and $F$ have their usual meanings. Then a theoretical sensitivity of $19.2 \mathrm{mV} / \mathrm{InC}_{\text {TFA }}$ was calculated according to eq. S2. Note that in this case we only measured the acidity change of organic solutions. To measure exactly the $\mathrm{pH}$ of organic solutions, we need to know the absolute $\mathrm{pH}$.
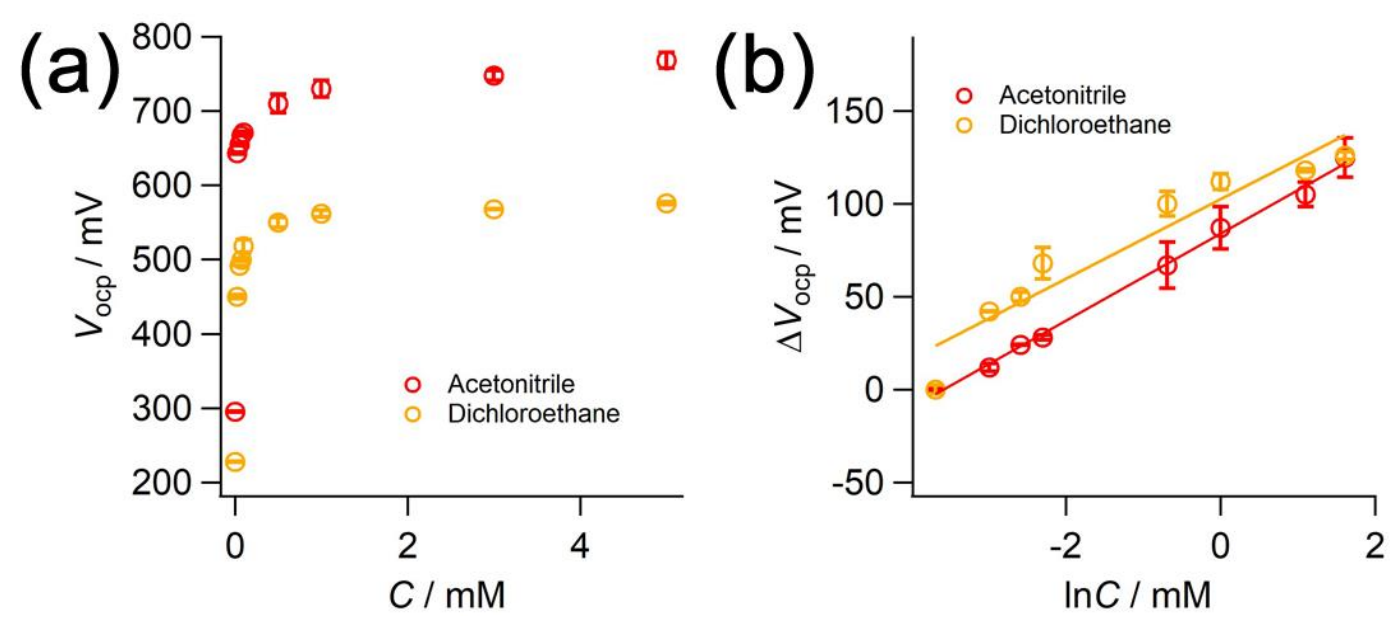

Figure S9. (a) OCP-acidity responses to the acidity in acetonitrile and dichloroethane. (b) The dependence of $\Delta V_{\text {OCP }}$ on In $C_{\text {TFA. }} \Delta V_{\text {OCP }}$ was the difference between $V_{\text {OCP }}$ with any concentration of TFA and $V_{\text {OCP }}$ with 0.025 mM TFA. 


\section{S12. Details on Flexible Epidermal pH Sensing}

Figure S10 shows the working process of the entire system. When the button battery is mounted to the battery holder on the flexible circuit board (the details of the flexible circuit board was shown in Figure S11), the power indicator (red LED on the FPCB) is illuminated and power management module begins to operate, providing a $3.3 \mathrm{~V}$ regulated voltage output for the entire hardware portion. The microcontroller (MCU) in the circuit starts to work, calls the embedded program pre-downloaded in the internal Flash, and sends a control command to the digital-to-analog conversion chip (DAC), then DAC can supply the voltage excitation signal to the potentiostat circuit. The potentiostat circuit operates under the voltage excitation signal, and collects the $\mathrm{pH}$ signal of the sweat from the $\mathrm{pH}$ sensor, and outputs it to the analog-to-digital conversion chip (ADC) through the signal processing unit of the potentiostat circuit. The microcontroller writes a control command to the ADC to enable analog-todigital conversion to convert the analog voltage signal from the $\mathrm{pH}$ sensor into a digital voltage signal, and the microcontroller reads the converted digital number from the ADC. The voltage signal is stored in MCU's internal EEPROM. When the data storage reaches a certain threshold, the MCU starts to initiate communication with the Bluetooth module, transmits the digital voltage signal to the Bluetooth module, the Bluetooth module turns on the broadcast, and broadcasts the digital voltage to the smartphone. At this point, one opens the APP on the smartphone to enable the Bluetooth connection function. Then one can read the sweat $\mathrm{pH}$ data from the $\mathrm{pH}$ sensor in real time on the interface of the APP. By calling the high-speed operation application programming interface (API), one can further perform statistical analysis and process $\mathrm{pH}$ data. Given $\mathrm{Cl}^{-}$in the sweat will influence the potential of printed $\mathrm{Ag} / \mathrm{AgCl}$ electrode, saturated $\mathrm{NaCl}$ solution was spread on skin surface before sticking the electrode.
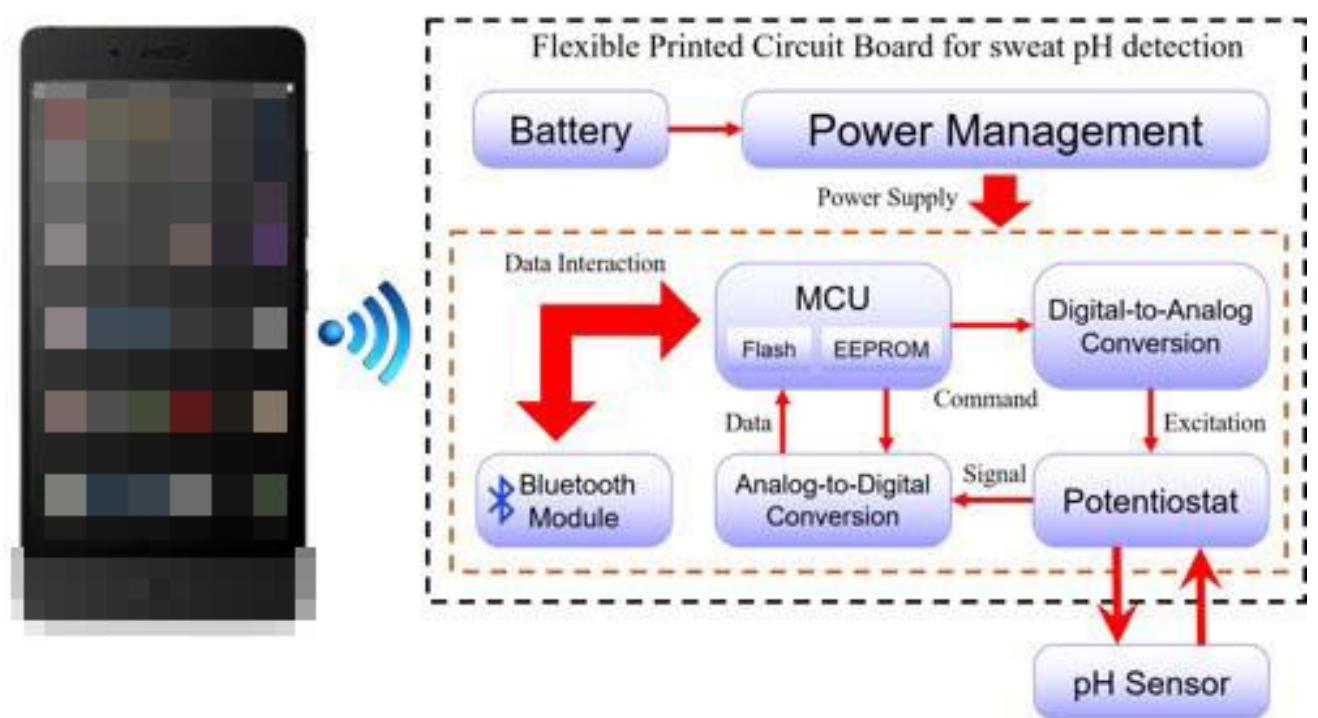

Figure S10. The description of the working process of the wireless $\mathrm{pH}$ detection system. 


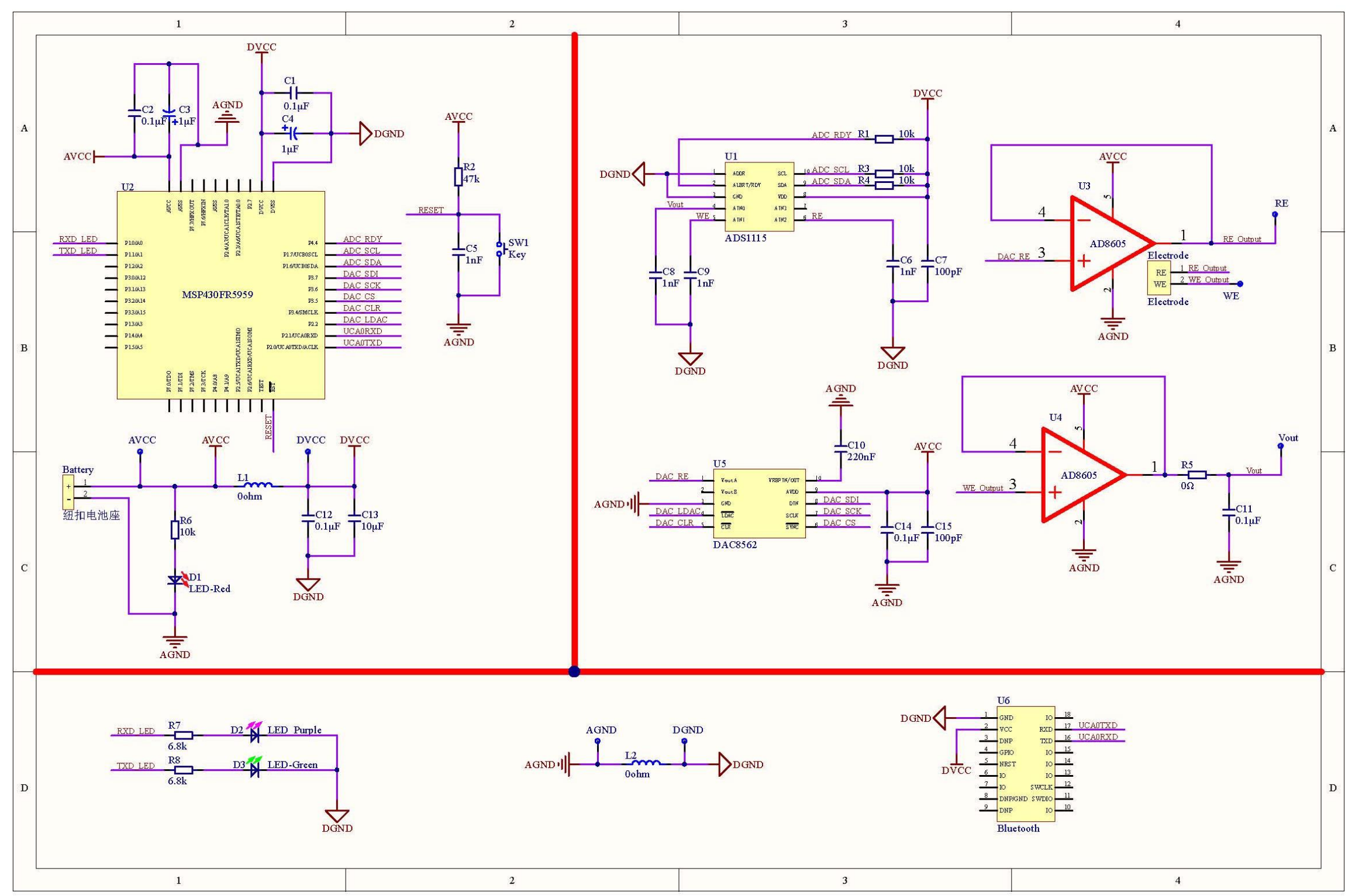

Figure S11. The details of the flexible circuit board. 


\section{S13. Performance of pH Sensor under Different Bending States}

Considering in practical use the wearable sensor is often bended to adapt to the human body surface, we also evaluated the analytical performance of our sensor under different bending angles. As displayed in Figure S12, for a 6-cm-long flexible sensor, it worked well when the bending angle was smaller than $40^{\circ}$. Beyond this angle, the sensor did not work properly.
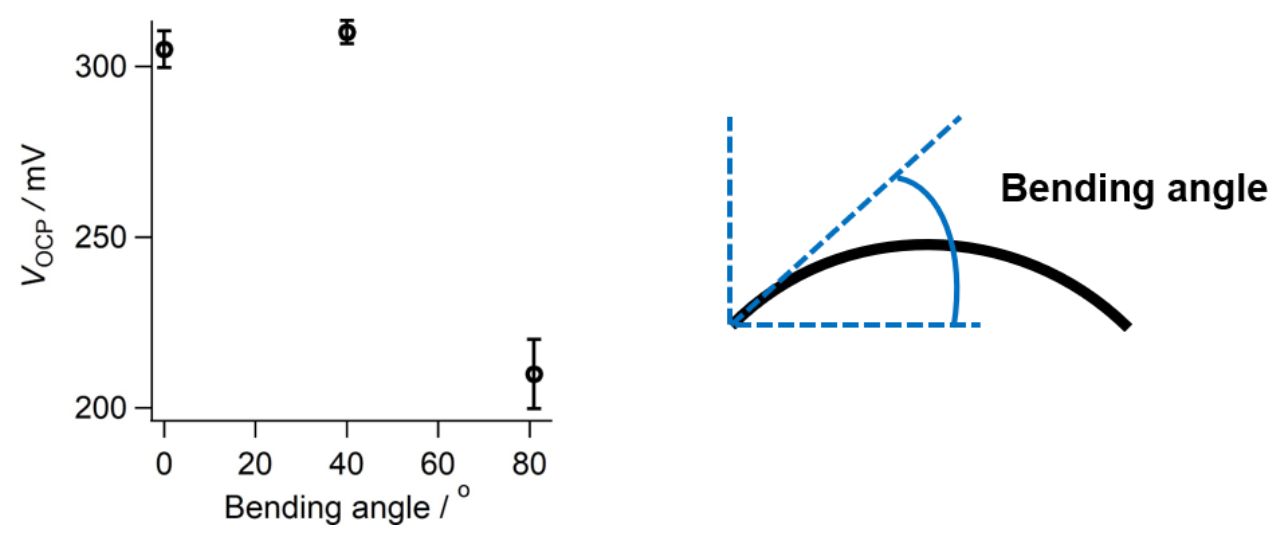

Figure S12. The OCP responses of wearable $\mathrm{pH}$ sensor at different bending angles in $1.0 \mathrm{M} \mathrm{NaCl}$ solution (pH = 6.5). 


\section{References}

(1) Zea, M.; Moya, A.; Fritsch, M.; Ramon, E.; Villa, R.; Gabriel, G. ACS Appl. Mater. Interfaces 2019, 11, 15160-15169.

(2) Chaisiwamongkhol, K.; Batchelor-McAuley, C.; Compton, R. G. Analyst 2019, 144, 1386-1393.

(3) da Silva, G. M.; Lemos, S. G.; Pocrifka, L. A.; Marreto, P. D.; Rosario, A. V.; Pereira, E. C. Anal. Chim. Acta 2008, 616, 36-41.

(4) Ratanaporncharoen, C.; Tabata, M.; Kitasako, Y.; Ikeda, M.; Goda, T.; Matsumoto, A.; Tagami, J.; Miyahara, Y. Anal. Chem. 2018, 90, 4925-4931.

(5) Prats-Alfonso, E.; Abad, L.; Casañ-Pastor, N.; Gonzalo-Ruiz, J.; Baldrich, E. Iridium oxide pH sensor for biomedical applications. 2013, 39, 163-169.

(6) Tolosa, V. M.; Wassum, K. M.; Maidment, N. T.; Monbouquette, H. G. Biosens. Bioelectron. 2013, 42, 256-260.

(7) Wu, C.-C.; Lin, W.-C.; Fu, S.-Y. Biosens. Bioelectron. 2011, 26, 4191-4197.

(8) Wang, M.; Yao, S. Electroanalysis 2003, 15, 1606-1615.

(9) Zhu, Z.; Ye, Z.; Zhang, Q.; Zhang, J.; Cao, F. Electrochem. Commun. 2018, 88, 47-51.

(10) Zimer, A. M.; Lemos, S. G.; Pocrifka, L. A.; Mascaro, L. H.; Pereira, E. C. Electrochem. Commun. 2010, 12, 17031705.

(11) Dong, Q.; Song, D.; Huang, Y.; Xu, Z.; Chapman, J. H.; Willis, W. S.; Li, B.; Lei, Y. Electrochim. Acta 2018, 281, 117126.

(12) Huang, W.; Deb, S.; Seo, Y.; Rao, S.; Chiao, M.; Chiao, J. C. IEEE Sens. J. 2012, 12, 487-495.

(13) Yu, J.; Khalil, M.; Liu, N.; Lee, R. Ionics 2015, 21, 855-861.

(14) Yamanaka, K. Jpn. J. Appl. Phys. 1989, 28, 632-637.

(15) El-Giar, E. E.-D. M.; Wipf, D. O. J. Electroanal. Chem. 2007, 609, 147-154.

(16) Jović, M.; Hidalgo-Acosta, J. C.; Lesch, A.; Costa Bassetto, V.; Smirnov, E.; Cortés-Salazar, F.; Girault, H. H. J. Electroanal. Chem. 2018, 819, 384-390.

(17) Sadig, H. R.; Cheng, L.; Xiang, T. J. Electroanal. Chem. 2018, 827, 93-102.

(18) Ardizzone, S.; Carugati, A.; Trasatti, S. J. Electroanal. Chem. 1981, 126, 287-292.

(19) Burke, L. D.; Mulcahy, J. K.; Whelan, D. P. J. Electroanal. Chem. 1984, 163, 117-128.

(20) O'Malley, M. J.; Woodward, P. M.; Verweij, H. J. Mater. Chem. 2012, 22, 7782-7790.

(21) Pan, Y.; Seyfried, W. E. J. Solution Chem. 2008, 37, 1051-1062.

(22) Kim, T. Y.; Yang, S. Sens. Actuators, B 2014, 196, 31-38.

(23) Olthuis, W.; Robben, M. A. M.; Bergveld, P.; Bos, M.; van der Linden, W. E. Sens. Actuators, B 1990, 2, 247-256.

(24) Wang, M.; Yao, S.; Madou, M. Sens. Actuators, B 2002, 81, 313-315.

(25) Zhu, Z.; Liu, X.; Ye, Z.; Zhang, J.; Cao, F.; Zhang, J. Sens. Actuators, B 2018, 255, 1974-1982.

(26) Lu, Y.; Wang, T.; Cai, Z.; Cao, Y.; Yang, H.; Duan, Y. Y. Sens. Actuators, B 2009, 137, 334-339.

(27) Baur, J. E.; Spaine, T. W. J. Electroanal. Chem. 1998, 443, 208-216.

(28) Ges, I. A.; Ivanov, B. L.; Schaffer, D. K.; Lima, E. A.; Werdich, A. A.; Baudenbacher, F. J. Biosens. Bioelectron. 2005, 21, 248-256.

(29) Huang, W.-D.; Cao, H.; Deb, S.; Chiao, M.; Chiao, J. C. Sens. Actuators, A 2011, 169, 1-11.

(30) Teng, Z.; Zheng, G.; Dou, Y.; Li, W.; Mou, C.; Zhang, X.; Asiri, A. M.; Zhao, D. Angew. Chem. Int. Ed. 2012, 51, 2173-2177.

(31) Streibel, V.; Jones, T.; Velasco Vélez, J.; Greiner, M.; Massue, C.; Arrigo, R.; Teschner, D.; Girgsdies, F.; Scherzer, M.; Allan, J.; Hashagen, M.; Weinberg, G.; Piccinin, S.; Haevecker, M.; Knop-Gericke, A.; Schlögl, R. Phys. Chem. Chem. Phys. 2015, 18, 2292-2296.

(32) Streibel, V.; E. Jones, T.; Velasco Vélez, J.; Massue, C.; Arrigo, R.; Teschner, D.; Girgsdies, F.; Scherzer, M.; Greiner, M.; Allan, J.; Hashagen, M.; Weinberg, G.; Piccinin, S.; Hävecker, M.; Knop-Gericke, A.; Schlögl, R. Surf. Interface Anal. 2015, 48, 261-273.

(33) Abbott, D. F.; Lebedev, D.; Waltar, K.; Povia, M.; Nachtegaal, M.; Fabbri, E.; Copéret, C.; Schmidt, T. J. Chem. Mater. 2016, 28, 6591-6604.

(34) Gao, J.; Xu, C.-Q.; Hung, S.-F.; Liu, W.; Cai, W.; Zeng, Z.; Jia, C.; Chen, H. M.; Xiao, H.; Li, J.; Huang, Y.; Liu, B. J. Am. Chem. Soc. 2019, 141, 3014-3023. 